\title{
Socio-Economic Upliftment of Women through Dairy Enterprise: A Study of in Barauni Dairy in Bihar
}

\author{
Shweta* and Ashok K. Singh
}

Department of Extension Education, Dr.Rajendra Prasad Central Agriculture University Pusa (Samastipur), Bihar - 848125, India

*Corresponding author

\section{A B S T R A C T}

\section{Keywords}

Social upliftment,

Economic upliftment, Dairy enterprises.

Article Info

Accepted:

06 July 2018

Available Online:

10 August 2018
The study has analysed the socio-economic upliftment of women through dairy enterprise. The study has been conducted in Begusarai district of Bihar by collecting data from 210 woman dairy co-operative society's members. From the study, it can be concluded that farm women have played an important role in the social and economic development of societies but they are often denied equal opportunities due to socially embedded gender inequalities. Though women contribute significantly to dairy production in Bihar, their participation in dairy farming is considered as an important tool for alleviating poverty and enhancing quality of life of rural community.

\section{Introduction}

Majority of population in India lives in villages where agriculture is the main economic activity. Besides crop farming, the domestication of animals has been integral part of the farming system from time immemorial. It is centuries old tradition for millions of Indian rural households (Khan et al., 2011). The advent of Green revolution, mechanization of farming and introduction of other modern agricultural practices has eroded the role of livestock in agriculture. However, livestock is still an integral part of agricultural production system and social fabric in India.
The important role played by dairy farming in the sustenance of landless and poor people in the village economy is quite evident (Pandey and Pathak, 1997).

The importance of livestock sector in general and of dairying in particular hardly needs emphasis in a country like India. The major and more widely known contribution of livestock sector is in terms of production of milk and milk products. Lack of infrastructural facilities along with low, scattered and seasonal milk production poses a serious problem of marketing that compels dairy farmers either to sell milk to the middlemen or to convert it into remunerative 
milk products. Under the situation, the organization of Dairy Cooperative Societies (DCS) seems to be only viable alternative for rural milk marketing under organized system.

The dairy cooperatives in India have three tier, of which consists of state level federations, district milk unions and dairy cooperative societies at the village level. As a result dairy cooperative societies have been organized to provide reasonable price to farmers, meet local demand for milk and eradicate the existing malpractices in milk marketing.

Bihar is a leading state in terms of agricultural productions and dairy farming has a significant contribution to agriculture GDP. Dairy farming is commonly practiced by the small and marginal farmers because these farmers have very small area of land to fulfill their needs, so they domesticate animals (Bhaskaran, 1996). Although dairy farming is not a specialized commercial activity but it provides regular income to farmers throughout the year and has a significant role in generating employment for women (Manish S. and Tanaka H., 2007).

In Bihar, animal husbandry and dairy is an important source of income and employment for millions of landless and play an important role in the socio-economic development in rural area. Women play an important role in dairy production hence establishment of a large number of women dairy cooperatives helped women increasing their participation in dairy production and marketing. But there are few studies in public domain which examined the influence of these societies on socio economic status of women through dairy cooperatives. Hence, the present study was undertaken at village level to understand the role of dairy co-operatives in the socioeconomic development of dairy women farmers.

\section{Materials and Methods}

Bihar State Co-operative Milk Producers' Federation Ltd. (COMFED) is the apex body of milk co-operative in Bihar. Barauni dairy is the largest milk union of the Eastern India located at Begusarai district in Bihar. Begusarai district is one of the largest producers of milk in Bihar and it has a very good network of co-operatives including women cooperatives with necessary infrastructure for the growth of livestock and milk production in the district. The nearness to the state capital city has further enhanced the growth of milk marketing due to high demand for milk. Barauni dairy collects milk from Begusarai, Khagaria, Lakhisarai and some part of Patna districts. Hence, Begusarai district was considered as the locale of present research which was identified purposely. There are altogether 18 blocks in Begusarai district. Among blocks of district, two blocks namely; Bachhwara and Bhagwanpur had larger number of WDCS in their jurisdiction and also having the largest women membership, hence these both blocks were identified for the study further, three WDCS from each block were selected randomly out of the total 20 WDCS of Bachhwara and 18 WDCS of Bhagwanpur block of Barauni district. For selection of women respondents as the sample of the study, a total of 35 WDCS members were selected from each identified WDCS of both the blocks by using proportionate probability technique. In this way the sample of the study consists of 210 members belonging to six WDCS.

Linear regression model was used to know the influence of independent variables on socioeconomic upliftment (dependent variable). The independent variables under study are age, education, type of family, type of house, caste, occupation, income from dairy and other sources. This model was adopted and carried out separately to know the impact of 
women dairy cooperative on social and economic upliftment of women through women dairy cooperative. The linear regression model and analytical form are mentioned as under

$\mathrm{Y}=\mathrm{a}+\mathrm{b}_{1} \mathrm{x}_{1}+\mathrm{b}_{2} \mathrm{x}_{2}+\mathrm{b}_{3} \mathrm{x}_{3}+\ldots \ldots \ldots+\mathrm{b}_{9} \mathrm{x}_{9}+$ $b_{n} x_{n}+e^{r}$

Where,

$\begin{array}{lll}\mathrm{y} & = & \text { Social upliftmentindex } \\ \mathrm{a} & = & \text { Constant } \\ \mathrm{x}_{1} & = & \text { Age }(\text { in years) } \\ \mathrm{x}_{2} & = & \text { Education (in years attended }\end{array}$
school/ colleges)

$\mathrm{x}_{3}=$ Type of family (Nuclear-1, otherwise-0)

$\mathrm{x}_{4}=$ Type of house (Pucca-1, otherwise-0)

$\mathrm{x}_{5}=$ Caste $(\mathrm{SC}-1$, otherwise- 0$)$

$\mathrm{x}_{6}=$ Occupation (Agriculture-1, otherwise-0)

$\mathrm{x}_{7}=$ Income from other sources (BelowRs 25000-1, otherwise-0)

$\mathrm{x}_{8}=$ Income from dairy (in Rs.)

$\mathrm{x}_{9}=$ Farmers' category (Marginal-1, otherwise-0).

$b_{1} \ldots \ldots . b_{n}=$ partial regression co-efficient $\mathrm{e}^{\mathrm{r}}=$ error term.

The above model was also used for determining economic upliftment of women to identify important factors of economic upliftment. The independent variables were also same as previous model. Economic indices were computed and used as dependent variables in the model.

\section{Results and Discussion}

Women development has been playing an important role in overall sustainable development of the nation. It is well understood that when a woman moves forward, the family moves and the village moves and the nation moves. Upliftment of women is an essential ingredient of human development. Women in rural sector are engaged in considerable amount of activities of farming and allied occupation. However, dairy activities are more liked and performed by farm women than crop farming activities. Dairy development has contributed positively to improve the economic and nutritional status of the rural areas. The lower income groups' i.e. landless class and marginal farmers in rural areas derived positive benefits from dairy development in terms of food intake and income even during the lean months (Bowonder et al., 1987). Dairy farming has been proved as a powerful instrument to further economic progress and social change, particularly in case of rural women.

An attempt was made to find out the main determinants of social upliftment. Social upliftment indices were worked out for each and every respondent's household which were regressed to their various socio-economic characteristics. For the purpose, linear regression model was adopted for in depth analysis. The details of result are presented in table 1 .

Social upliftment index was considered as dependent variable whereas age, education, type of family, type of house, caste, occupation, income and farmers' category were taken as independent variables. The findings revealed that the co-efficient of determinants $\left(R^{2}\right)$ is 0.4489 , indicating that 45 per cent variations in socio-economic status of members of WDCS is explained by variable included in the model. The co-efficient of age is negative $(-0.0042)$ but significant at 1 per cent level of probability. Hence, it may be said that younger members of the WDCS command higher level of social order than older one. Co-efficient of income level (0.2599) and income from dairy (0.0513) are positive and statistically significant at 1 per 
cent level of probability, indicating that these two variables are affecting significantly to social upliftment of members of WDCS. Hence, higher the income level along with higher income from dairy are likely to improve the social status of women members of WDCS. While formulating model, S C was assigned 1 , others 0 and the Co-efficient of caste was found negative $(-0.0604)$ but it is significant at 5 per cent level of probability, indicating the higher caste in social hierarchy command higher social status among members of WDCS.. Co-efficient of occupation is positive (0.0549) and significant at 10 per cent level of probability, indicating that women members with agriculture as main occupation command higher social status than members with occupation as labour, artisan etc. Occupation also emerged as a significant determinant of social status of women members of WDCS The variables such as; education level, type of house, farmers' category and type of family could not exert any significant influence on social status of women members of WDCS. However, several variables responsible for social upliftment were not included in model because some of them were either not quantifiable or not measurable.

In the light of above discussion it is evident that income flow has direct bearing on social status of women. Economic status of women members of WDCS improved due to increase in various components which have direct influence on economic status of the respondents. However, various socioeconomic variables of women members might have played significant role in enhancing their economic status. For the purpose a linear regression model was also adopted for identifying important economic variables affecting enhancement of economic status of women members. Economic index was taken as dependent variable and age, education, type of family, type of house, caste, occupation, and income level and farmers' category were considered as independent variables. The result of analysis is presented in table 2 .

Table.1 Regression co-efficient and respective Standard error of variables of social upliftment

\begin{tabular}{|l|c|c|c|}
\hline \multicolumn{4}{|c|}{ Dependent variable $=$ Social } \\
\hline Explanatory variables & Coefficient & Standard error & T value \\
\hline Age & $-0.0042^{* * *}$ & 0.0013 & -3.29 \\
\hline Education & -0.0030 & 0.0034 & -0.87 \\
\hline Type of family & 0.0063 & 0.0279 & 0.22 \\
\hline Type of house & -0.0131 & 0.0276 & -0.48 \\
\hline Caste & $-0.0604 * *$ & 0.0286 & -2.11 \\
\hline Occupation & $0.0549 *$ & 0.0312 & 1.76 \\
\hline Income & $0.2599^{* * *}$ & 0.0298 & 8.72 \\
\hline Income from dairy & $0.0513^{* * *}$ & 0.0178 & 2.88 \\
\hline Farmers' category & 0.0105 & 0.0303 & 0.35 \\
\hline Constant & $1.5830^{* * *}$ & 0.0763 & 20.75 \\
\hline No. of observation & 210 & & \\
\hline R-squared & 0.4489 & & \\
\hline Adj R-squared & 0.4241 & & \\
\hline ***, ** and * indicate 1, 5 and 10 \% level of significance, respectively. & \\
\hline
\end{tabular}


Table.2 Regression co-efficient and respective standard error of independent variables responsible for economic upliftment of WDCS members

\begin{tabular}{|l|c|c|c|}
\hline \multicolumn{5}{|c|}{ Dependent variable = Economic index } \\
\hline Explanatory variables & Coefficient & Standard error & T value \\
\hline Age & $-0.0033^{* * *}$ & 0.0011 & -3.00 \\
\hline Education & -0.0042 & 0.0029 & -1.46 \\
\hline Type of family & -0.0214 & 0.0237 & -0.90 \\
\hline Type of house & -0.0159 & 0.0233 & -0.68 \\
\hline Caste & -0.0167 & 0.0242 & -0.69 \\
\hline Occupation & 0.0070 & 0.0264 & 0.26 \\
\hline Income & $0.2275^{* * *}$ & 0.0252 & 9.01 \\
\hline Income from dairy & $0.0000^{* * *}$ & 0.0000 & -2.63 \\
\hline Land class & 0.0054 & 0.0257 & 0.21 \\
\hline Constant & $1.7380^{* * *}$ & 0.0646 & 26.90 \\
\hline No. of observation & 210 & & \\
\hline R-squared & 0.4355 & & \\
\hline Adj R-squared & 0.4101 & & \\
\hline
\end{tabular}

$* * *, * *$ and $*$ indicate 1,5 and $10 \%$ level of significance, respectively.

It may be observed from the table that the coefficient of determination $\left(\mathrm{R}^{2}\right)$ is 0.4355 , indicating that 45 per cent of variation in income was explained by variables included in the study. It was expected also because in qualitative variable, the $\mathrm{R}^{2}$ does not cross more than 0.50 hence the model is quite fit to our data. The co-efficient of age is negative (0.0033 ) but significant at 1 per cent level of probability which clearly indicates that income level of women is inversely related to age of women. The younger women were likely to command higher economic status than aged women. Co-efficient of income level and income from dairy were positive and significant at 1 per cent level of probability, indicating that the women earning higher income particularly through dairying commands higher economic status. The coefficient of educational level, type of family, type of house, caste and occupation were not found statistically significant hence, it may be concluded that these variables don't have any influence on economic status of women members of WDCS in villages under study.
On the basis of above discussions it may be concluded that the WDCS exerted positive impact on enhancing socio-economic status of women members of WDCS. Younger women of higher caste with higher level of income commands higher social status. Hence, it may be inferred that the caste hierarchy still has some bearing in social status in rural Bihar. But the caste does not play any significant role in enhancing economic status of women members. Younger women command higher social and economic status in rural area. Agriculture occupation is not preferred in rural area but women with agriculture as main occupation command higher social and economic status in rural Bihar. Qualitative factors like; education, type of family and type of house are not important factors for higher social and economic status in rural Bihar Therefore, time has come to make concerted efforts to address gender issues through providing support for technological and economic empowerment of women to increase their socio- economic status. 


\section{References}

Bandhyopadhyay M.K. (1996) Dairy cooperative and rural development. Finance India, X (2): 406-411.

Khan N., Salman M.S. and Rehman A. (2011) Livestock husbandry in rural urban fringe of Alighar Town: Environmental Sustainability. Advanced Journal of Geographic World, 1 (2): 18-27.
Manish S. and Tanaka H. (2007) The impact of dairy co-operatives on Women Empowerment- A case of kishan dairy co-operative in West Bengal, India. Sabaragamuwa University Journal, 17 (1): 64-77.

Pandey V.N. and Pathak A. (1997) Peasants, subsistence and the dairy co-operative in dry land: A fragile existence, 32 (39): A98-A105.

\section{How to cite this article:}

Shweta and Ashok K. Singh. 2018. Socio-Economic Upliftment of Women through Dairy Enterprise: A Study of in Barauni Dairy in Bihar. Int.J.Curr.Microbiol.App.Sci. 7(08): 783-788. doi: https://doi.org/10.20546/ijcmas.2018.708.087 